\title{
THE UNFIXED STATE OF UNFIXED LAND
}

\section{Nikita Sud, University of Oxford}

\begin{abstract}
Land is unfixed. Qualitative research in India shows humans physically reconfiguring, legally redefining, politically re-labeling and discursively reimagining land in growth and investmentled policies. The state is a key actor in the material and conceptual unfixing of land, and its refixing to emerging developmental imaginations. But land is not just a territorial container for the implementation of policy. Instead, it routinely stretches the boundaries of state authority. In my field sites, unfixed, multi-dimensional land emerges as contested access, social and political territory-making, possession that goes beyond the legality of property, and more. As unfixed land extends past the boundaries and authority of the state, the state too is stretched in projects of land's unfixing and re-fixing. This state is revealed as porous, and with a crisscrossing of social relationships that draw out its institutional bounds into a world of moonlighting officials, revolving doors, and shadowy actors and transactions over unfixed land. The result of this co-productive interaction is the unfixed state of unfixed land.
\end{abstract}

\section{Introduction}

Land is not a 'thing' ( $\mathrm{Li}, 2014 \mathrm{a})$, or an immovable abstraction. Instead, it is infused with dynamism, both physical and socio-relational. Land is the surface of the earth, and what lies below it, plus us. Dynamic land is constantly changing materially and in meaning. Over the years, a diverse scholarship on land has pointed us away from the axiom of fixity, which suggests that land is the solid and dry surface of the earth (Park and Allaby, 2017; Samuelson and Nordhaus, 2010). Instead, it has confronted land's inherent sociality and variability. Several decades ago Polanyi (1944) wrote about the fictitious nature of land as a commodity. Land is not readily available for sale and purchase; one plot of land is not easily interchangeable with another. Land has to be taken to market (Nevins and Peluso, 2008); it is commodified via human action. Lefebvre (1974/1991) adds to the critique by pointing to land's many dimensions. For him, land is agriculture, property, and territory; it is economics and politics. Along these lines, Hall (2013) examines land as territory, property and an object of regulation. Li (2014b) too suggests that the uses and meanings of land are not stable; they can be disputed. The value of land is not intrinsic. It is a flexible assemblage of material substances, technologies, discourses, practices, policies, politics and power. Rasmussen and Lund (2018) discuss processes of reterritorialization under expanding capitalism. Here, 
existing patterns of spatial control, authority and institutional orders are fundamentally challenged and replaced by new uses and users of resources.

My understanding furthers research that views land as social, processual and multidimensional. Drawing from the extant literature, I combine a nuanced appreciation of land with ideas of human-nature co-production. The latter suggest that from the beginning of human history, but accelerating as the modernisation process has intensified, the objects and subjects of daily life have become increasingly melded, or more socio-natural (Swyngedouw, 2015: 20; also Latour, 1993). The nature-human relationship is co-productive (Bakker and Bridge, 2006), in that the materiality of nature and our sociality are intertwined (Whatmore, 2002). Histories, geographies and societies are made by non-human entities, as much as by humans (Castree, 2005). Building on these insights, I posit the simple idea that we make the land, just as the land makes us. To elaborate on this, I explore the land-state interaction.

The paper first interrogates the many meanings of land in my field sites. It converses with a vast, multi-disciplinary literature on land that does not necessarily speak across subject boundaries. It then advances the idea of unfixed land that shapes the argument. Land is central to the identity, territorial boundaries, policies and practices of the state. In the second section, I discuss the evolving, many-hued engagement of the state with unfixed land via policy, informalized practice and politics. As the state wends its way through the unfixity of land, it is made and re-made, dispersed and stretched outwards into a myriad social relationships. Unfixed land reciprocally engendering an unfixed state is the subject of the third section. Before delving into the argument, I discuss the context and methodology of the study.

My research is based in India. Since economic liberalisation in 1991, there have been farreaching changes in India's land. According to government data, between 1991 and 2012, land for non-agricultural uses such as manufacturing, infrastructure, mining, services and real estate has risen by over 5.6 million hectares. Simultaneously, land used as commons has declined (Government of India, 2014). So-called wasteland, which studies show (Baka, 2013; Gidwani, 2013) is actually used for agriculture, shelter, pasture, the collection of plant produce, etc. has declined by 2.5 million hectares. Land designated as pasture has gone down by 1.5 million hectares. Net sown agricultural land has decreased by 3 million hectares (Government of India, 2014). These figures are reflected in India's 'land wars' (Levien, 
2012, 2013; Roy, 2014; Steur, 2015). These are oftentimes violent struggles in the wake of dispossession, faced by poor and farming groups dependent on the commons and agrarian employment. The targets tend to be the land gaining rich, who are seen as accumulating resources at the expense of the poor, with the active facilitation of the state (Harvey, 2003). Projects synonymous with India's post-liberalisation economy have been the crucibles of India's land wars, be it private Special Economic Zones, factories, mines and refineries, townships and gated communities, or large public or private infrastructure installations such as ports, highways, and high-speed rail lines (Levien, 2018; Neilsen, 2018; Roy, 2014; Sud, 2009 among others).

The current, dynamic moment of India's economy is a high-definition context for this study. I have been exploring ongoing land transitions in favour of India's privatising secondary and tertiary sectors since 2003. The last round of fieldwork was in August-September 2015, though I have followed relevant happenings in my field sites using documentary and online sources till the time of writing. In terms of sites, the research draws on data collected in Gujarat in western India and West Bengal in eastern India. This multi-sited collection of data has been driven by India's land regime, wherein land is a State ${ }^{1}$ subject in the Constitution. That is, land is officiated by the federal units of the country. At the same time, repeated, field-based research compelled me to look past the official, regulating state, as it acted on land. My reaching past the officiousness of policy and regulation renders trite any neat comparison between Indian States.

My sources of data for this argument are varied, and cover qualitative research methods such as semi-structured interviews, group discussions, ethnographic observation, and the in-depth perusal of media, policy, judicial and NGO documentation. I have conducted over 250 interviews with a range of stakeholders in land and the state in India. Key stakeholders have been interviewed and observed on an ongoing basis. Overall, I have interviewed high-ranking and junior bureaucrats across scale, ranging from the capital Delhi, to the sub-national capitals of Gandhinagar and Kolkata, and further down to the city and village. Besides officials, I have met a range of consultants, touts and other kinds of intermediaries who hang around the offices and functions of the state. Further, the research covers politicians, business

\footnotetext{
${ }^{1}$ In the following pages, state with a small 's' refers to the apparatus of government, broadly defined, and further delineated below. State with a capital 'S' connotes the federal units of the Indian Union.
} 
people, land buyers, sellers and brokers, professionals such as town planners, architects, real estate developers, chartered accountants, lawyers and financiers who deal with land. Finally, I have interviewed observers and other participants in India's ongoing land transition, such as journalists, NGO workers and activists, and academics. Any name used in the research is a pseudonym, to protect the identity of my informants. I also use pseudonyms for locations smaller than sub-national states or major cities, with an eye on maintaining confidentiality.

The sub-national locations of my study are vast. To focus the research, I have zoned in on three sites of ongoing changes in land and land use: (a) a large, private infrastructure project in a small coastal town in Kachchh, Gujarat, with linked manufacturing units in surrounding villages. (b) Peri-urban Kolkata, West Bengal, which is a hub of urban real estate and service-sector activity. Besides these locations, I also draw on field material from my research sites in other parts of the States of study, e.g. Ahmedabad city. As indicated above, in most of these sites, land for the uses of the new economy is being drawn largely from the commons, and agriculture and related pursuits.

The long-term nature of this research, conducted using a range of sources, has generated a vast amount of data. My manuscript draws on this data to build and illustrate the argument. The data is taken from different sites of research in a purposive manner. Some sites of research, and sources of data better illuminate certain points of my argument. Instead of neatly, and somewhat artificially etched comparison, I am more interested in illustrating wide-ranging changes in land that are afoot in India. I intend to use this study of transition to shed light on the nature of land, as also the state that is intervening in and shaping these changes. The purposive rather than systematic drawing on the data available to me builds ' $a$ ' argument about the co-productive relationship between land and the state, rather than 'the' argument. Any claim to representativeness in a vast country and subject of study such as mine is unrealistic. However, the broad scope of the data, and its long-term nature, makes the claims I am making robust.

\section{Unfixed, multi-dimensional land}

Land is variable. It varies over time; it varies in meaning; and it changes materially. Long term field research in India, followed by iteration with extant conceptualisations of land, lead me to propose the following dimensions of land that are relevant to my research sites: enlivened land, land as territory, land that is governed, including via property, and land as 
access and exclusion. To elaborate, land is infused with history and memory (Alexander, 2006; Ulloa, 2005). Humans revere it as a provider, mother, a store of identity and belonging (Munster, 2017). In my field sites, people regularly seek divine forgiveness by touching the soil and then their forehead, before stamping on the ground. In all these cases, instead of the land possessing agency per se, divinity, sociality and memory are invoked in the land via human action. Humans enliven land.

As territory, land lends identity to the state. Territory is not a given (Agnew, 1994). It is a political technology that is produced, mutable and fluid (Elden, 2010). It comprises active techniques for measuring, ordering and mapping, as also legal and political mechanisms for controlling and producing landed terrain, and maintaining its boundaries (Elden, 2009). The formal territorialising practices of the state are amply visible in my field sites. For instance, there is regular police patrolling near industrial installations on account of 'terror alerts'. This is especially so in regions proximate to international borders, such as my study location in Kachchh, Gujarat, which is easily accessible from Pakistan via land or sea. Territory is also claimed and asserted within the boundaries of the state. It is social, economic and political dominance over space in its everyday form (Benbabaali, 2018). Thus in a process that enlivens as also territorializes land, the developers of a port-based private infrastructure project in my study site of Kachchh have built a magnificent temple to the Hindu lord Hanuman on the sea coast, within the project's precincts. My informants proudly indicate that 'Hanuman is pawan putra [son of the wind god], he controls winds and storms.' ${ }^{2}$

Overlooking environmental caution, the infrastructure project is built in a cyclone-prone area. The spirit of the wind god is thus being invoked to protect the enterprise, its workers and promoters from the furies of nature. The cultural landscaping of the business also affirms the control of its new landowners over a potentially contentious territory, intermediated by the securitising state and the gods.

Land as territory needs to be ordered and managed in the everyday. Here land is associated with authority, and becomes the means for deploying this authority. The state organizes its territorialized national space as an economy and polity (Mitchell, 2002). A key mechanism adopted by the state for controlling its territory is the governance of land via the deployment of its authority. The highly political state that I am concerned with regulates land policy, land

\footnotetext{
${ }^{2}$ Interview, 22 December 2008
} 
use and its ownership. In turn, the state is shaped by its interventions in land. For instance, a state that proactively opens up land markets in its territory gets termed pro-business and successfully attracts further investment (Sud, 2014). Not just the state, but also non-state actors claim territory. Non-state actors deploy their authority in territorialized space. Nonstate actors may derive influence through proximity to the state, and may be categorized as being in the shadows or margins of the state (Das and Poole, 2004; Harriss-White, 2003).

Besides being enlivened, territory and authority, land is crucially property. Property is the legal and implementable right to benefit from a tangible or intangible resource (Lund, 2011; Ribot and Peluso, 2003). The state adjudicates ownership rights over land through the creation of property, in turn taxing property holders in an enduring relationship. The state's property laws gain power by appearing as rational abstractions (Blomley, 2014; Mitchell, 2002). In real life, these abstractions are fought over, as I show shortly in the quote below. Moving away from the dominance of property, Ribot and Peluso (2003) see land through the frame of access. Access is not the right but the ability - direct or indirect - to derive benefit from things. Access to land would depend on an evolving constellation of factors, including power, politics, social and economic resources, etc. This access could be expressed via the powers of possession (Sikor and Lund, 2009).

The flip side of the ability to access and possess land, would be the capacity to exclude others from it. As Hall, Hirsch and Li (2011) tell us, the state, market, community and political actors may exercise such powers of exclusion. Demonstrating powers of access and exclusion over land is this quote from one of my interviewees in village Lahiyaria, Kachch. The village is proximate to the mega infrastructure project of my field research. The village itself houses a large, export-oriented manufacturing facility. The location of the infrastructure and manufacturing projects has set off a land rush in the area. The quote from JB, an ex-village head and current political notable plus land broker needs to be read in this context. He says with his characteristic swagger:

Whatever [property] title we can get on the land is good. And sometimes if there is very seedha sadhaa [straightforward] title, we can also spoil it. Power is in kabza [access via possession]. You [the farmer seeking to sell land to a Company via JB the broker] don't sleep in the khet [field] do you? No you don't. I will just send five men; they will go and sit in your khet at night. Next morning they will put [a] fence on your khet. Now will you want to fight me in court or just settle with money?... Everybody is scared of Court chakkar [rounds of the Courts].

- Interview, Village Lahiyaria, 12 August 2015 
In this quote, my interviewee is asserting his authority over land. He derives this authority from the lingering influence of his official position in the village, and from his social standing. His position, and his skills as a land broker allow him to manipulate and move between land as property, as also land as access and exclusion.

Opening up the many meanings of land via field research is empirically enriching. However, there is only so much to be gained by moving from ideas of land as a 'thing' to land as a property-thing, territory-thing, etc. That land is complex and variable is only one step in the building of the proposition of unfixity that frames this paper. A further step is to indicate, as I have demonstrated above, that land is variable and transitional in time and over time. Unfixed land may occupy multiple registers simultaneously, for instance those of property, territory and enlivenment. It may also transition from one register to another. Unfixed land may be refixed, say to current development agendas. Thus, as in the case of my Kachchh field site, coastal land that has multiple meanings and claimants can be appropriated for infrastructure, via the apportioning of property status. However, the social, political, economic and material life of land would not end at this point (also Appadurai, 1986). Land that appears to have been commoditized for the projects of big capital in Kachchh continues to be contested over access and exclusion by displaced fishworkers, farmers and pastoralists. With its sensitive border location, this land is still a high security zone guarded intensively by the state. It is also sacred space, with the upper caste Hindu and Jain-run businesses, as also lower caste and Muslim fishworkers and pastoralists continuing to worship in and around it.

In defining land as unfixed in meaning, in time and over time, in space and across space, this paper is not proposing a utopian idea of, say, multi-dimensional land defying deep structural changes. After opening up the definition of land as 'unfixed', much of the rest of this paper shows land being appropriated for the contemporary march of capitalism, with accompanying spatial changes such as expanding cities, and zones of neoliberal production. However, instead of linear change towards market-aligned forms of land as commodity, the paper highlights the continuation of many lives, or socially intertwined trajectories, of land. Besides representing the many lives of land as they exist in practice, it is hoped that an emphasis on land's unfixity, even in these times, inspires further creative research as well as politics. 
As a final point on the framing of the paper through land's unfixity, it is important to underline that I portray land as materially as well as conceptually unfixed. In the socionatural perspective adopted in the paper, the material changeability of land is produced by social relationships. Yet, where the physicality of land as nature ends, and where the sociality of human meanings, relationships and institutions begins is difficult to delineate (also D’Souza, 2006; Khan, 2015; Krause and Strang, 2016). This socio-natural dynamism is portrayed in the paper through synonyms around land's multi-dimensionality, malleability, changeability, and fluidity. The many lives of land merit this diversity of language. This multiplicity matches unfixed land as it is in the world around us. Moreover, in research that is inductive, or where theory building and analysis emerge from its empirical material, physically and conceptually unfixed land now provides the analytical window for understanding land-state interactions in the next section. I deploy land's unfixity to analyse the world it co-produces.

\section{The state and unfixed land}

One of my fieldwork States, Gujarat, has an impressive record of opening up its land markets to facilitate economic liberalisation. For instance, it has removed residence restrictions on the sale and purchase of land if this is for an industrial purpose. Till the mid-1990s, only a local resident, living within 8 kilometres of the land, could purchase it. Similarly, the state allows for agricultural land (A) to be converted to non-agricultural uses (NA) without a fee to encourage manufacturing (Sud, 2014). This pro-activeness in 'liberalising land' has earned Gujarat the moniker of being 'business-friendly', as opposed to the more 'sluggish' ${ }^{3}$ West Bengal. According to a former West Bengal land department official, who now consults with private firms looking for land in the State, 'here even for change of use of land from NA to NA, government permission is required. So draconian.' 4 This draconian, interventionist impression is deepened when one considers that no business or other entity in the State is allowed to own more than 7 standard hectares of land for any purpose whatsoever. Some entities like tea gardens, mills, factories and others can go over these ceiling limits, but only with the written permission of the government (Government of West Bengal, 1999).

Businesses see these 'archaic' ownership restrictions as 'killing' enterprise' ${ }^{5}$. In short, Gujarat's state exercises its authority on land via market-facing policy, and is in turn labelled

\footnotetext{
${ }^{3}$ Term used in the press, and repeated by my land broker interviewee, in Kolkata, 24 August 2013

${ }^{4}$ Retired official, interviewed in Kolkata, 26 December 2011

${ }^{5}$ Real estate developer, interviewed in Kolkata, 22 December 2011
} 
pro-active and business-friendly, even by itself (Government of Gujarat, 2003, 2009). Conversely, West Bengal's state is seen as acting less favourably towards market openness, and is called sluggish and draconian.

If land were a 'thing' to be acted on and fixed in place, then the seemingly opposite trajectories of the states of Gujarat and West Bengal in the post-liberalisation context would also be given. The labels attributed to the two states in their differing policy engagement with land would stick. However the state, as also the material it is working with in my case: land, is highly elastic. Being mandated as ceiled at 7 standard hectares per person, or officially and freely convertible from A to NA for industrial purposes, does not decree that the life of land will follow this official trajectory. Even if the officially mandated trajectory were to be somewhat followed, the continuities and unfixities in land, and the relationships around it, compel us to look at the story beyond this signpost. I follow through this assertion with a detailed example from Gujarat.

I developed a healthy scepticism for the much-touted market-facing, business-friendly initiatives of Gujarat's state during conversations with bureaucrats who had a bird's eye view of the policy landscape. I had repeatedly interviewed some of these officials, and also had a social acquaintance with them. This allowed for a more open interaction than would normally have been possible in research on the state. The bureaucrats in question had helped draft some of Gujarat's pioneering initiatives in land. For instance, one bureaucrat had headed the Department of Industry in the period of liberalisation, and another was the serving head of the Revenue Department that officiated the land policies I was interested in. I have kept the dates of my conversation deliberately vague to protect the officials' identity.

Pointing to row upon row of housing estates on the outskirts of the commercial capital Ahmedabad, Gujarat's senior most land official appeared helpless. 'This was supposed to be a green belt, the lungs of the city. But it has disappeared, given way to apartments. I don't know how this was allowed.' ${ }^{6}$ A few years later, his former compatriot from the Industries Department expressed pride at Gujarat's record of land liberalisation policies. He also said not many people availed of, say, automatic A to NA conversion. 'It is [still] too long a process; it is legal but little used. The extra-legal route is to pay Rupees 10 to 40 per square

\footnotetext{
${ }^{6}$ Interviewed in Ahmedabad, 26 September
} 
yard, for conversion. The money is paid to panchayat [village council] members, ministers, the party [in power]. People are very happy with this conversion arrangement. There is no $\mathrm{ad}$ hocism (sic). An industrialist told me, everyone knows the rate. In other States it is arbitrary, depends on the mood of officials ${ }^{3}$. In both these interactions, some of the senior most officials dealing with the land portfolio were telling me that much-admired regulatory policies related to land and its governance were flouted as a matter of course. This makes it untenable to go on studying the state and land through official channels only.

From the previous section, we know that land is unfixed, and it transitions across its many dimensions over time. In the case of Ahmedabad's disappearing green lungs, which seemed to come as a surprise to my civil servant interviewee, adopting the framework of unfixity makes transitions in the belted land more fathomable. The official state may have inscribed its regulatory authority over the land by decreeing a green belt. However, that is not where the journey of that land ends. In 2004, the Ahmedabad Urban Development Authority (AUDA) inaugurated a 76 kilometre long, 60 metre wide Ring Road encircling the city. The road, and related projects, drastically expanded Ahmedabad's jurisdiction. It brought 15,378 hectares of largely rural and agrarian land within the expanded urban limits (Mittal, 2014). The road was officially announced in 1999, with the publication of AUDA's 2011 Development Plan. However, discussions with local architects suggest that select architects, civil engineers, real estate developers and politicians in the city were aware of the new infrastructure initiative in advance of the official announcement. As one such person told me, 'the government's pet businessmen and developers bought land in the proposed new city limits before the announcement and made a killing. The understanding was of a 60:40 division... that means, after the official announcement, when the land price jumped, the buyer kept 60 per cent of the profit from sales, and top people within AUDA got 40 per cent. Some of this was personal, the rest went to the Party. ${ }^{8}$

In the 1990s, the then greenhorn Bharatiya Janata Party (Indian Peoples' Party, BJP) was on the rise in Gujarat. It formed its first State government in 1995, amidst political upheaval, and only gained a steady footing in the State in 1998 after several experiments with unsteady coalitions. From 1998, it has remained in power till date. In 2014, the long-serving Chief

\footnotetext{
${ }^{7}$ Interviewed in Ahmedabad, 24 December

${ }^{8}$ Architect and Planner, interviewed in Ahmedabad, 20 October 2004
} 
Minister of the State, the BJP's Narendra Modi was catapulted to the Prime Ministership of the country. To many, the expansion of Ahmedabad was key to the party's putting down roots in the political and economic life of Gujarat and beyond. The putting down of roots is quite literal in the case of urban expansion discussed above. The malleability of unfixed land is key to this rooting. In 1998, the Party appointed the dynamic civil engineer and real estate developer Surendra Patel to the chairmanship of AUDA. Patel knew the land and building ecosystem of the city, but was also a consummate politician. Not coincidentally, his AUDA chairmanship coincided with a key position within the Party: that of Treasurer. Patel's skills as a fundraiser are widely recognized in Gujarat. The local media regularly carries admiring notes on him, openly suggesting that 'he is seen as someone who can cough up crores at a moment's notice'9. The building of the Ring Road augmented this ability.

The ungreened-belt I had witnessed during field research was not part of the Ring Road development. However, it was proximate to it. The frenzied building activity that took place in Ahmedabad as the Ring Road took shape, in all likelihood swallowed the green belt. This act of informal, possibly politically sanctioned incorporation, was under the radar of part of the state machinery, including my official informant. Informalized urban expansion marks the burgeoning cities of the Global South (Bayat, 2000; Roy, 2005; Kudva, 2009; Lombard and Rakodi, 2016). Delving into urban studies debates on this issue is outside the remit of this word-limited paper. I consciously focus on land in changing spaces, instead of on the spatial form of the city or village. At the same time, my work speaks to ongoing debates on the city. A central issue therein is the role of the state in urban expansion. For some, new forms of space such as edge cities, SEZs and new town development are being 'conceived outside the state' (Shatkin and Vidyarthi, 2014: 15; Sami, 2014). For others, the state deliberately unmaps and un-plans cities (Roy, 2009). This allows it to practice authority and accumulation unencumbered by regulation. At the same time, the state's informality may slow it down, opening it to challenge and multiple pressures (Benjamin, 2008; Holston, 2009; Roy, 2009). Furthering the latter claim, the remainder of this section interrogates the life of land in a case of urban planning that has gone significantly off-grid. The next section dwells on what this tells us about the nature of the state that un-plans, un-maps, and in the terminology of this paper, un-fixes and re-fixes land.

\footnotetext{
${ }^{9}$ https://timesofindia.indiatimes.com/city/ahmedabad/BJPs-money-bag-in-cash-richstate/articleshow/576126.cms, accessed 21 February 2019
} 
Based on several cases of the surreptitious takeover of the commons in my other field sites ${ }^{10}$, it can be conjectured that Ahmedabad's state authorized green land underwent several contortions on paper and in practice, before taking the shape of the apartments my bureaucrat interviewee and I witnessed. The now un-green belt may have experienced the stealthy cutting or burning of flora, and/or the dumping of construction waste to flatten the vegetation ${ }^{11}$. Land that was enlivened as the anthromorphized 'lungs of the city', even if within the modernist grid-like vision of the state, would have been eviscerated and de-valued, only to be re-valued at a later date. It may subsequently have undergone tussles over political access and exclusion, battles over who could control it, and with the patronage of which part of the political and state machinery ${ }^{12}$.

The paperworking of the land, and its re-entry into the official ambit of registered property may have somewhat settled political contestations over it. At least these tussles would have taken the background, when the land once again did the rounds of the official state, to be rerecognized: as property, as a cartographic artefact, and as a government record. We know in retrospect that by the time my interviewee and I witnessed the ex-green belt, it had entered the official record once again in the form of 'regularized colonies' ${ }^{13}$. Regularization is a process of official recognition of land that may have been 'unauthorized' either in the form of an informal settlement, or as in the example above, as a state-sanctioned green belt that has been privately appropriated over time. Regularisation officially brings this land in the ambit of state services, thus providing renewed legitimacy to the land. In regularising the land, the state tacitly condones the multiple processes of land unfixing and re-fixing that have gone into the spatial transition under study (also Zimmer, 2012).

Having gone through various processes of unmaking and re-making, the land under discussion would have entered the property space from which it would have been ready for the market. This commoditized land would then have been built over in the form of apartments, shops, leisure areas and other products of urban space, which my official

\footnotetext{
${ }^{10}$ Field observation and interviews, Lahiyaria, August 2015; various interviews, Kolkata, 2011, 2012, 2013

${ }^{11}$ Land broker and strongman, interviewed in Lahiyaria, 14 August 2015; architect, interviewed in Ahmedabad, 20 October 2004.

${ }^{12}$ Ibid.

${ }^{13}$ Bureaucrat, interviewed 26 September 2004; Architect, interviewed 20 October 2004
} 
informant had dejectedly pointed out to me. For analytical purposes, I have presented the possible trajectory of the un-green-belted land in a somewhat linear fashion. In practice, the many processes and contestations on this land could have been simultaneous, messy and far from linear. Further, the officially regularized and commercially property-ized building over of a former green belt is, of course, not the end of the road for this unfixed land. There would be continued tussles over the provision of urban services and infrastructure (Berenschot, 2011; Gupte, 2017), the availability of political patronage and protection, enduring security concerns, and ongoing experiences of sacralisation and enlivenment. Ahmedabad, after all, is replete with contestations over space being appropriated for temple building and community consolidation. Road sides are prominent markers of these struggles, and there is no reason to believe that the acres of former green-belt within the city is shorn of such battles (Bobbio, 2015; Ghassem-Fachandi, 2012). In fact, a short drive through the area's roads today reveals several makeshift structures such as roadside temples and shops. We can be sure that tussles over territory, authority and access, besides the sacral enlivenment of these temple lands, is ongoing $^{14}$. In short, the life of land carries on, with or without the sanction of the official, topdown state.

States all over the world keenly, and compulsively, ascribe their authority on land. But this land does not lie prone; it is not merely moulded into the vision of the land regulating, land ordering state. Not-prone land, unfixed land escapes the vision of the top-down state. In Ahmedabad, a green belt gets absorbed in a politically driven attempt to expand the city. In West Bengal, wetlands get swallowed up in the drive for urban expansion, even as the official state holds on to its laws of ownership restriction (Roy, 2009; Sengupta, 2013; Sud, 2017). The formal state's will to improve, order, authorize and govern is resisted in many ways $(\mathrm{Li}$, 2007; Scott, 2009), and this is certainly the case for land. Recalcitrance to the authority of the state can come from the people it seeks to order, as also from land and nature that remain unruly in the face of official decree. Indeed, elements of the state itself, and the politics in which this state is embedded, can overturn or at least refract from official will.

In its multi-dimensional and transitioning lives, land has multiple authorities exercised on it: the official authority of the policy-making state, but also the political authority of those

\footnotetext{
${ }^{14} \mathrm{https}$ ://timesofindia.indiatimes.com/city/ahmedabad/temple-extension-razed-ingurukul/articleshow/57710794.cms, accessed 1 February 2019
} 
exercising their powers of social access and exclusion over this land, and the shadow authority of those who derive power from the state but may not occupy office within it, or are indeed moonlighting from this office. The criss-crossing of land's unfixity along the contours of the state begs the question: how is the state entangled with land's unfixity? I explore answers in the next section.

\section{The unfixed state of unfixed land, or the stretchable state in the shadows}

Philip Abrams (1988) told us that the state is an idea, as also a system comprising institutions made up of accreted practices (Evans, 1995). Beyond the disaggregated, and far from coherent state idea and state system, to believe there is 'a state' out there is 'a triumph of concealment' (Abrams, 1988: 77). In the previous section, we have seen the state as less than cohesive in its interactions with society over unfixed land. My field interlocutors, including those involved in the takeover of the commons, socialise with members of the state, seeking an 'in', a 'channel' into its machinations ${ }^{15}$. In letting societal and business agendas 'in', in being so embedded in society and politics that it is actually stuck or unable to implement its policies, the state is already breached. The breaching of the state-its influencing by political demands (Damodaran, 2008; Rudolph and Rudolph, 1987), and by dominant classes (Bardhan, 1998; Chibber, 2003; Frankel, 2005), is well researched in the study of politics in India and beyond (Evans, 1995). However, this breaching, or infiltration in terms of demands, interests and ideas, tends to happen within 'the state', i.e. within Abrams' triumph of concealment.

It is when we acknowledge the anthropology of the state (Das and Poole, 2004; Fuller and Benei, 2001; Gupta and Ferguson, 1997; Hansen and Stepputat, 2001; Sharma and Gupta, 2005), that the breaching of the state through politics and policy compromises, societal entanglements and more, begins to go past fairly defined boundaries of stateness. Here the state has 'blurred' boundaries (Gupta, 1995), it is informalized (Roy, 2009) and exists in 'shadows' (Harriss-White, 2003). Increasingly, this 'pluralised state' (Chandhoke, 2003) of multiple and parallel authorities is also a 'hybrid' (Jaffe, 2013). In this state of hybridity, the pluralizing shadows and parallel machineries that exercise authority, actually become entangled with the formal state in relationships of collusion and divestment. The state

\footnotetext{
${ }^{15}$ High-end land broker and lawyer, interviewed in Kolkata, 24 August 2013; leading real estate developer, interviewed in Kolkata, 19 December 2012, to cite a few
} 
becomes diversified and hybridized (Jaffe, 2013: 734-5). It is in this space of the extendable and flexible boundaries of stateness that I place my work. My contribution to the literature cited here is to draw out the entanglement of nature, in this case land, in the jagged making and re-making of the state ${ }^{16}$.

My real estate developer contact Jax waved his hand impatiently when I studiously went through a checklist of land laws that I thought he might encounter during the construction of a building in the outer-reaches of Kolkata city. 'Laws, regulations are a nuisance. They delay a project, raise the costs. We have to find ways around [them]. ${ }^{17} \mathrm{He}$ proceeded to list a range of people in or out of official positions who could be consulted, politicians who could be brought on board, consultants who could be deployed, and lawyers, chartered accountants and others who could be used to work around regulations, find legal or extra-legal solutions to 'problems' such as ceilings on land ownership, or prohibitions on using wetland and other waterbodies for construction. Jax's compatriot Nolun also listed the range of people who could be used to do this kind of 'government work' involving meeting, or more likely skirting the requirements of the law. Nolun then added, 'sometimes we do directlygovernment work. Sometimes we outsource to people who do this work regularly-makes things easier.' ${ }^{18}$

I would argue that the quotes above point to the stretchiness of land which furthers the stretchiness of the state, and vice versa. Both the states under study: business-friendly Gujarat, as also ostensibly recalcitrant West Bengal, have private firms make 'ins', or seek channels of familiarity and pliability into the state. The firms' relationship of breaching the boundaries of the state is built around historical and practical knowledge of the porous and socially embedded nature of the state as the literature and interviews referenced above suggests. Crucially, it is also built around the unfixity of land which allows for this continued breaching. Thus, Jax knows that ceiling restrictions set by the state are pliable, just as the land that is sought to be contained within state regulation is pliable. Or riverbeds, wetland

\footnotetext{
${ }^{16}$ On these lines, see Swyngedouw (2015) on water in politics-making and state-making in $20^{\text {th }}$ century Spain (also Bakker, 2010), and Weszkalnys (2014) on the anticipated discovery of oil wending its way through the social and political life of Sao Tome.

${ }^{17}$ Interviewed in Kolkata, August 2012

${ }^{18}$ Interviewed in Kolkata, August 2012
} 
and waterbodies are not off-limits for construction because these can 'simply be filled in' and 'built over' 19 .

How does quotidian knowledge wherein 'everybody knows' that land can be moved in and out of official regulation, begin to form institutionalized patterns? How does the perpetual unfixing and re-fixing of land become part of the nature of the stretched-out state? The constant making and re-making of land is not one-off. It is deeply embedded in the practices of the state. The accretion of these practices produces some institutional patterns, which are visible in my field sites. I go over three such institutional accretions of the stretched-out state: the moonlighting official, the revolving door, and the shadow state or the men who sit outside the office as they go about processes of unfixing and re-fixing land to the needs of India's economy, society and polity. I contend that these institutional accretions render the stretchedout state making and re-making land's unfixity, and being made and re-made in turn, routine (also Das and Poole, 2004).

In numerous instances in my field sites, members of the state themselves push past the boundaries of official decree. Typically, this is done through processes of 'moonlighting', wherein serving state personnel embark on informal, private consultancy arrangements for a fees. Take for instance the case of a moonlighting policeman, who I met during fieldwork in Kolkata. In a dingy, dusty land office in one of my field sites, I came across a police subinspector. He was appealing with land officials for a land lease extension for a small plastics manufacturing company. The Company had deployed him for liaison with the local state. The company had taken land from the government for another purpose, but was now set to alter its business. The Company wanted to continue on the same plot, thus going against the rules of the government-facilitated business park where it was located ${ }^{20}$. After the policeman left, the two officials I was interviewing indicated that he did this extra, interceding job on a regular basis for clients on his beat. The porous, stretched out authority of the moonlighting official does not run parallel to the state (contra Eggen, 2011). Instead, it draws on the official state, and also edges the state outwards. In the process, this stretched out authority further loosens the bounds of unfixed land.

\footnotetext{
${ }^{19}$ Land broker and political party member, interviewed in Kolkata, August 2014

${ }^{20}$ Field notes, Writer's Building, Kolkata, 21 December 2011
} 
Moonlighting is only one step removed from the revolving door, wherein an official who may have been offering services to a private party then altogether leaves government service to join a private entity as a consultant or employee. The revolving door is visible across the globe (Blanes I Vidal et al, 2012). It is prevalent across sectors in India, especially after liberalisation when arenas hitherto controlled by the government have been privatised (also Chatterjee, 2015). In the context of land, I came across several examples of the revolving door, spanning official status. Clerks and junior bureaucrats, as also the most senior officials were involved. I spoke to former Chairs of State Infrastructure Development Boards and Industrial Development Corporations, and Secretaries of Industry, Land Revenue, and Housing. Post-retirement, they were employed as Consultants by large companies to do their 'government work', or to handle the government relations that embed this work ${ }^{21}$. Similarly, relationship-based government work on the ground was being done by former Deputy Collectors or other former local land officials, who knew the ins and outs of the law, as also the ways and people to get around it. The large infrastructure project I have studied in Gujarat, for instance, employed the former Deputy Collector of the area to head its land procurement department ${ }^{22}$. At more exalted levels sub-nationally and nationally, the same project had more senior consultants who had been associated with the government in senior bureaucratic roles. Such insider-outsiders are central to the unfixed state of unfixed land.

The state that engages with and broadly incorporates insiders-turned-outsiders like the availers of the revolving door, is also associated with outsider-insiders. The latter would be people who are outside the formal institutions of the state but nonetheless carry authority to possess land, territorialize it, process paperwork to propertyize it or unmake its property status, to erect or sanction religious structures or boundaries to make this land disputed or out of reach for some, etc. The many insider-outsiders, as well as outsider-insiders criss-cross the stretched out state, populating it, and making it what it is. A ubiquitous form of outsiderinsider visible in my field sites is 'the man who sits outside [the office]'. This is an exact translation of an explanation from a former Block Land and Land Reforms Office (BLLRO) clerk who now serves a private firm dealing in land. For him, 'mahuri matlab jo aadmi bahar bethta hai. Depending on work in BLLRO, you can have 10-20 mahuris sitting there... so

\footnotetext{
${ }^{21}$ Interviews with government officials turned private consultants in Ahmedabad 20 December 2008; Kolkata 22 August 2012

${ }^{22}$ SEZ official, interviewed on site, 22 December 2008
} 
many. ${ }^{23}$ Given their ubiquity, routineness, numbers, and location, the men who sit outside the office are quite literally in the shadows of the state. Mahuris are a Bengali phenomenon, but any government land office visited in the course of this research revealed multiple men who sit outside the office.

Bustling around official compounds; sitting within or just outside boundary walls — on chairs, on the ground, under trees, and in makeshift stalls; filling in and carrying paperwork to the 'sahibs' (sirs) inside, or files and information from the inside to those waiting eagerly outside; these men act as gatekeepers, facilitators, scribes, and go-betweens. The men, and very occasionally women, link the land regulating, land authorising, land ordering, and land irregularizing and dis-ordering state, with buyers, sellers, owners, paper holders, and paper seekers of land. Variously called mahuris, touts, social workers, brokers, pyraveekars, helpers, etc. (Manor, 2000; Oldenburg, 1987; Reddy and Haragopal, 1985), these are 'essential lubricants' who bridge the distance between the state and the public (Berenschot, 2011). In the perception of the public they serve, these outsider-insiders who work in the shadows of the state are the state. In some cases, supplicants such as those looking to register a land deal, change a record of ancestry, or retrospectively mark a change in the physical geography of land, will not see the officials who sit inside government offices till much later in the process, if at all. The bulk of their interactions with the 'state' happen in the shadows. In the process, the men outside the government office become an extension of the state. They get paid by clients, who call them dada and $\operatorname{sir}^{24}$; one a term of familiarity, the other of deference. The stretched out state is familiar, but still maintains some of the trappings of the more distant core of the state.

Clearly, the shadows of the state bridge the gap between the seemingly distant state and the public. At the same time, theirs is more than a bridging role. In the shadows, land is continuously unfixed and refixed, sometimes in contravention of state authority over this land. For instance, in the first section we came across a political notable, who is also involved in land brokering and government paperwork. He referred to the spoiling of seedha sadha (straightforward) property title if the situation demands. He recognised that power lies

\footnotetext{
${ }^{23}$ Former government clerk, interviewed in Kolkata, 29 August 2013

${ }^{24}$ Interviews, and field observations, Block Land and Land Reform Office, Greater Kolkata, July, August 2014.
} 
in possessing land or kabza, irrespective of the legal niceties of property title ${ }^{25}$. From detailed fieldwork on this and related cases, we know that it is officials who shuttle between official and private work, often with the intercession of 'men who sit outside the office' who intervene to get land which has entered the realms of access and exclusion beyond property, officially recognised as 'disputed'. As an interviewee in Kachchh put it, 'in some 7/12 [property papers named after the number of the relevant government form], it can be that on top there is the name of the maalik [owner] and below is name of kabzedaar [possessor]. Name of kabzedaar comes when Talaati [local land official] does so through panchnaama [official procedure to recognise disputed ownership]. Then if land is to be sold, kabzedaar will also get money. Kabzedaar comes in through testimonies of local people' ${ }^{26}$.

The person who has acts of land's unfixing and possession recognised, and officially recorded, is a resourceful man who sits outside the office. He works in tandem with a local Talaati official, who also easily moves in and out of his official role. It could even be argued that the constant making and un-making of disputed land, as in the case above, empowers the tout and the Talaati, and keeps them in business. The shadows of the state, and the other institutional accretions of the spread-out, porous state such as the moonlighting official, are fully invested in the multi-faceted, unfixed life of land. Multi-faceted, undulating land keeps a porous, proliferating, shadowy state in business. Quite far from attempts to streamline land regimes, computerise land records, or reform land tenure as official state decrees and international donors such as the World Bank are wont to do (Deininger, Selod and Burns, 2012), the many lives of unfixed land carry on. Land spills past the formal authority of the state not as an aberration, but because the spilled over state and spilled over land co-produce each other. In the process, land and the unfixed state remain central to the societies, polities and economies they are intertwined in. It is for this reason that processes of un-mapping (Roy, 2009), disordering and unfixing are intrinsic to my field sites, and well beyond. Despite longstanding human attempts to tame and institutionalize nature, both nature and human institutions have continued to challenge the centralising, ordering, will to govern and improve $(\mathrm{Li}, 2007)$. The socio-natural unfixity of land is central to this story as this paper has highlighted.

\footnotetext{
${ }^{25}$ Interview, Kachchh, 12 August 2015

${ }^{26}$ Ex-village head, interviewed in Kachchh, 15 August 2015
} 
The porosity of the state as depicted in this section, as also the institutional accretions that make and re-make this stretched-out state, are not unique to the post-liberalisation era in India. The literature cited at the start of this section also includes pre-1991 studies. At the same time, the introductory section demonstrated increasing transition of land towards India's post-liberalisation economy which privileges the secondary and tertiary sectors over agriculture. I also touched on a regime of regulation to 'liberalize land' from the 1990s in Section 2. In this context of changing state priorities and regulation, the scope for the unfixed state of unfixed land has also grown manifold. This state is beyond analyses of businessfriendliness (Kohli, 2012), porosity (Sinha, 2019) or corruption. This is a state that comes into being due to its deep, and increasing entanglement with socio-natural land. This is the unfixed state of unfixed land.

The unfixed state of unfixed land exposes a stretched out, relational order of society. From a state that has been interpreted in recent history as distant from, undecipherable to (Scott, 1998), and even above society (Alavi, 1982), the socialised stretching outwards of the state makes it more accessible to interests from within society. Yet, the state of unfixity that I have portrayed in this paper is far from a people's state. Even the stretched-out state is deeply embedded in structures of caste, class and gender. In my field sites, the moonlighting officials, touts, gatekeepers, consultants, and related others tend to be from socially powerful and well-connected groups. It is the privilege of some groups to attempt an association with the rather forbidding state. These groups may possess the social capital to find as 'in' to the workings of the state, or to get involved in 'government work'.

The lower caste and Muslim fishworkers, pastoralists and marginal farmers who have been displaced by the infrastructure Zone in Kachchh, for instance, do not have easy 'ins' into the unfixed state. Their approach to the state is replete with statist obstructions and gatekeepers. This does not mean that they don't deploy the unfixity of land in their claims to this resource. Their claims to land as livelihood, access, mother, or longstanding connection to the earth, are made to the state, the courts, and most forcefully via political action and protest. I analyse the political challenging of the unfixed state, and its allies in society and business, in a forthcoming publication. For this paper, it is pertinent to indicate that the unfixed state of unfixed land is a socio-naturally entangled state. It is a state that thrives on disordering regulatory frames around land. But this disorder aligns with, and by and large deepens 
dominant social order. This is the order where proximity to the state, knowledge of how the stretched-out state works, and facility with the many dimensions of land, are used to enhance societal power. The unfixity of land, and the state it co-produces, are social ordermaintaining. Not order-changing.

\section{Conclusion}

This article set out to explore unfixed land, in a push back against ideas of land's fixity. Unfixed land is conceptually and materially malleable. It is also transitional between the many registers it occupies, be it enlivenment as sacred, history or memory; state authority and territory; the state adjudicated right to property; as also the ability to go against this in forms of access, possession and exclusion from the land. In putting forward a multidimensional, dynamic idea of land's unfixity, the article has furthered a diverse literature that engages with land beyond its 'thingness', or existence as a platform for human capture and construction.

While land is far from a static thing, it is continuously made and re-made, or unfixed, refixed, and unfixed in the language of this article, by human action and human institutions. As literature on human-nature interactions is telling us, there is no such thing as untouched nature, separate from human influence. Not only is unfixed land produced and re-produced by humans and their institutions, the latter are also made and re-made via their actions on the land. The relationship between land and the institutions that act on it is co-productive.

The institution through which this article chose to study the land-human interface is the state. The state derives its authority from its shaping of land and land policy, and via the control of territory. In the case of the sub-national states of my study in west and east India, acting on land in the current moment of economic liberalisation and private investment-led growth, characterises these institutions as business-friendly or less so. Yet, land is not simply a container for the actions of the state. Multi-faceted land moves in and out of the ambit of the state, well past acts of formal policy-making. This undulating trajectory of land is best studied by zoning in on a case, as I have done with Ahmedabad's disappearing green belt. Despite the authorisation and territorialisation of a green belt by the state, what remains of this initiative is a concrete jungle. The latter is the product of political and urban expansion, with a formally decreed green belt undergoing many contortions on and in the land to get to the point it is at today. Yet, the undoing of state authority via registers of access, possession 
and ultimate regularisation and commodification as property does not spell the end of the life of this land. The un-greened belt continues to be contested over sacred spots, political authority, and more. The life of unfixed land carries on, despite and beyond commodification.

While land is continually unfixed and re-fixed, the state is hardly static in this process. The final section of the article dwelled on the unfixed state of unfixed land. An undulating, porous, stretchy, shadowy, even unfixed state, thrives in an ecosystem of unfixed land. This state spills over into shadows as it unfixes and re-fixes land, going well past its formal authority. This spilled over state is made up of a currency of relationships, proximity, channels in, and the drawing of favours and services out. The proliferating, porous state of unfixed land is accreted in the form of accepted, routinized practices that institutionalize porosity. Here, moonlighting officials, a revolving door, and a vast world of shadows keep land's unfixity in motion. As land is constantly made and re-made, so is the vast, stretched out state. This is the mutually reinforcing, co-productive, unfixed state of unfixed land. The detailed, field-based research underlying this paper furthers literature on the many dimensions of land, urban un-planning, and the everyday state cited above. A consolidated concept of unfixed land, and its tying in with an unfixed state via a framework of socionatural co-production shows us the consequences of unfixity on both the state and land. It tells us the story of contemporary India from a unique perspective.

As a final point for this article, we have to ask if the unfixed state is a generally existing phenomenon, or if land brings something in particular to our understanding of the nature of this entity. It could be argued that states are multi-layered, embedded in sociality and relationships, as also porous and shadowy across the board. The career of a steel or soap bar from the process of manufacture to trade and sale would also reveal the multiplicity of the state. Yet, it could be argued that the stretchiness of land reveals, and also enhances, the stretchiness of the state. The wending of unfixed land through the state, its offices and back offices, is particularly revealing of the lives and afterlives of the state. Similarly, a state of order and control, which is also opened out, loopholed, and porous, tolerates and even engenders the many lives of land. The unfixity of land and the state are intertwined, and especially illuminating of an entity like the state that is anyway porous, shadowy, and riven with sociality. 
Related to this point about the particularities of my subject of study would be the question of unfixed land and co-productively unfixed institutions being a third world or Southern occurrence. Is it that institutions with more capacity, for instance in the global North, would officiate land in less unfixed ways? This question is open to research. What I have attempted is the start of a conversation about land's unfixity. Even in contexts where, say, land that is state authorized property cannot overnight be unfixed via possession, or via alternate territorialisation, land remains not a thing. In any milieu, it can be confidently vouched that land occupies multiple registers and wends its way through multiple institutions, relationships, histories, socialites and politics. This multi-dimensional land no doubt engenders varied institutional relationships. This varied life of land, irrespective of geography, needs to be interrogated seriously. This is especially in a context where we are moving away from modernist views of nature being the object of institutional capture. If we make nature, just as nature constantly makes and re-makes us, then the lives of land and institutions explored in this article, point to a vast and under-explored arena of study.

\section{References}

Abrams, P. (1988) 'Notes on the Difficulty of Studying the State', Journal of Historical Sociology, 1(1): 58-89

Agnew, J. (1994) 'The Territorial Trap: The Geographical Assumptions of International Relations Theory', Review of International Political Economy, 1(1): 53-80

Alavi, H. (1982) 'State and Class Under Peripheral Capitalism', in H. Alavi and T. Shanin (Eds.), Introduction to the Sociology of Developing Societies', London: Macmillan, pp. 289307

Alexander, J. (2006) The Unsettled Land: State-making and the Politics of Land in Zimbabwe 1893-2003. Oxford: James Currey

Appadurai, A. (1986) (Ed.) The Social Life Of Things: Commodities In Cultural Perspective. Cambridge: Cambridge University Press

Baka, J. (2013) 'The Political Construction of Wasteland: Governmentality, Land Acquisition and Social Inequality in South India', Development and Change, 44(2): 409-28

Bakker, K. and G. Bridge (2006) 'Material worlds? Resource geographies and the 'matter of nature', Progress in Human Geography, 30(1): 5-27

Bakker, K. (2010) Privatizing Water: Governance Failure And The World's Urban Water Crisis. Ithaca: Cornell University Press

Bardhan, P. (1998) The Political Economy Of Development In India. Oxford: Basil Blackwell 
Bayat, A. (2000) 'From 'Dangerous Classes' to 'Quiet Rebels': Politics of the Urban Subaltern in the Global South', International Sociology, 15(3): 533-557

Benbabaali, D. (2018) 'Caste dominance and territory in South India: Understanding Kammas' socio-spatial mobility', Modern Asian Studies, 52(6): 1938-76

Benjamin, S. (2008) 'Occupancy Urbanism: Radicalizing Politics and Economy beyond Policy and Programs', International Journal of Urban and Regional Research, 32(3): 719-29

Berenschot, W. (2011) Riot Politics: India's Communal Violence And The Everyday

Meditation Of The State. London: C. Hurst \& Co. Publishers Ltd.

Blanes i Vidal J., M. Draca and C. Fons-Rosen (2012) 'Revolving Door Lobbyists', American Economic Review 102(7): 3731-48

Blomley, N. (2014) 'Disentangling Property, Performing Space', in M.R. Glass and R. RoseRedwood (Eds.) Performativity, Politics And The Production Of Social Space. New York:

Routledge, pp. 147-75

Bobbio, T. (2015) Urbanisation, Citizenship And Conflict In India: Ahmedabad 1900-2000.

London: Routledge

Castree, N. (2005) Nature. London: Routledge

Chandhoke, N. (2003) 'Governance and the Pluralisation of the State. Implications for Democratic Citizenship', Economic and Political Weekly, 38(28): 2957-68

Chatterjee, E. (2015) 'Underpowered: Electricity policy and the state in India, 1991-2014',

DPhil thesis, University of Oxford

Chibber, V. (2003) Locked In Place: State-building And Late Industrialisation In India.

Princeton: Princeton University Press

D'Souza, R. (2006) Drowned And Dammed: Colonial Capitalism And Flood Control In

Eastern India (1803-1946), New Delhi: Oxford University Press

Damodaran, H. (2008) India's New Capitalists. NY: Palgrave

Das, V. and D. Poole (Eds.) (2004) Anthropology In The Margins Of The State: Comparative Ethnographies. Oxford: James Currey Ltd.

Deininger, K., H. Selod, A. Burns (2012) 'The land governance assessment framework: Identifying and monitoring good practice in the land sector', Agriculture and Rural Development, Washington DC: World Bank. https://openknowledge.worldbank.org/handle/10986/2376?locale-attribute=en, accessed 25 June 2019

Eggen, O. (2011) 'Chiefs and Everyday Governance: Parallel State Organisations in Malawi', Journal of Southern African Studies, 37(2): 313-31 
Elden, S. (2009) Terror And Territory, London: University of Minnesota Press

Elden, S (2010) 'Land, terrain, territory', Progress in Human Geography, 34(6): 799-817

Evans, P. (1995) Embedded Autonomy. States And Industrial Transformation. Princeton, NJ:

Princeton University Press

Frankel, F.R. (2005) India's Political Economy 1947-2004. The Gradual Revolution. Second Edition, Oxford: Oxford University Press

Fuller, C.J. and V. Benei (Eds.) (2001) The Everyday State And Society In Modern India.

London: Hurst and Company

Ghassem-Fachandi, P. (2012) Pogrom In Gujarat: Hindu Nationalism And Anti-Muslim

Violence In India. Princeton, NJ: Princeton University Press

Gidwani, V.K. (2013) 'Six theses on waste, value, and commons', Social and Cultural Geography, 17(7): 773-83

Government of Gujarat (2003) Gujarat Industrial Policy, Gandhinagar: Government of Gujarat

Government of Gujarat (2009) Kachchh Package, District Industries Centre, Bhuj, 31/03/2009. http://ic.gujarat.gov.in/?page_id=3185, accessed 8 February 2017

Government of India (2014) Agricultural Statistics At A Glance 2014, Directorate of Economics and Statistics, Ministry of Agriculture. Delhi: Oxford University Press Government of West Bengal (1999) The West Bengal Land Reforms Act, 1955 (As modified up to the $1^{\text {st } J a n u a r y, ~ 1999) . ~ K o l k a t a: ~ G o v e r n m e n t ~ o f ~ W e s t ~ B e n g a l ~}$

Gupta, A. (1995) 'Blurred Boundaries: The Discourse of Corruption, the Culture of Politics, and the Imagined State', American Ethnologist, 22(2): 375-402

Gupta, A. and J. Ferguson (Ed.) (1997) Culture, Power, Place: Explorations In Critical Anthropology. Durham: Due University Press

Gupte, J. (2017) “These streets are ours': Mumbai's urban form and security in the vernacular', Peacebuilding, 5(2): 203-17

Hall, D., P. Hirsch and T.M. Li (2011) Powers Of Exclusion: Land Dilemmas In Southeast Asia. Honolulu: University of Hawai'i Press Hall, D (2013) Land, Cambridge: Polity Press Hansen, T.B. and F. Steputtat (2001) States of Imagination: Ethnographic Explorations of the Postcolonial State. Durham, NC: Duke University Press

Harriss-White, B. (2003) India Working. Cambridge: Cambridge University Press Harvey, D. (2003) The New Imperialism, Oxford: Oxford University Press 
Holston, J. (2007) Insurgent Citizenship: Disjunctions Of Democracy And Modernity In Brazil. Princeton, NJ: Princeton University Press

Jaffe, R. (2013) 'The hybrid state: Crime and citizenship in urban Jamaica', American Ethnologist, 40(4): 734-748

Khan, N (2015) 'River and the Corruption of Memory', Contributions to Indian Sociology, 9(3): 389-409

Krause, F. and V. Strang (2016) 'Thinking Relationships Through Water', Society \& Natural Resources, 29(6): 633-38

Kudva, N. (2009) 'The Everyday and the Episodic: The Spatial and Political Impacts of Urban Informality', Environment and Planning A, 41: 1614-1628

Latour, B. (1993) We Have Never Been Modern, translated by Catherine Porter. Cambridge, MA: Harvard University Press

Lefebvre H. (1974, 1991) The Production Of Space. Oxford: Blackwell Publishers

Levien, M. (2012) 'The land question: Special Economic Zones and the political economy of dispossession in India', The Journal of Peasant Studies, 39(3-4): 933-69

Levien, M. (2013) 'Regimes of Dispossession: From Steel Towns to Special Economic Zones', Development and Change, 44(2), 381-407

Levien, M. (2018) Disposession without Development: Land Grabs in Neoliberal India. New York: Oxford University Press

Lombard, M. and C. Rakodi (2016) 'Urban land conflict in the Global South: Towards an analytical framework', 53(13): 2683-2699

Li, T.M. (2007) The Will To Improve: Governmentality, Development And The Practice of Politics, Durham, NC: Duke University Press

Li, T. M. (2014a) 'What is Land? Assembling a Resource for Global Investment', Transactions of the Institute of British Geographers, 39: 589-602

Li, T.M. (2014b) Land's End: Capitalist Relations On An Indigenous Frontier. Durham, NC: Duke University Press

Lund, C. (2011) 'Fragmented Sovereignty: Land reform and dispossession in Laos', The Journal of Peasant Studies, 38(4): 885-905

Manor, J. (2000) 'Small-time Political Fixers in India's States: “Towel over Armpit”, Asian Survey, 40(5): 816-35

Mitchell, T. (2002) Rule Of Experts: Egypt, Techno-Politics, Modernity. Berkeley: University of California Press

Mittal, J. (2014) 'Self-financing land and urban development via land readjustment and value 
capture', Habitat International, 44: 314-23

Munster, D. (2017) 'Zero Budget Natural Farming and Bovine Entanglements in South India', in Troubling Species: Care and Belonging in a Relational World', by The Multispecies Editing Collective, RCC Perspectives: Transformations in Environment and Society, No. 1: 25-32

Nevins, J. and N.L. Peluso (2008) (Ed.) Taking Southeast Asia To Market: Commodities, Nature, And People In The Neoliberal Age. London: Cornell University Press

Nielsen, K.B. (2018) Land Dispossession And Everyday Politics In Rural Eastern India. London: Anthem Press

Oldenburg, P (1987) 'Middlemen in Third-World Corruption: Implications of an Indian Case', World Politics, 39(4): 508-35

Park, C. and M. Allaby (2017) A Dictionary Of Environment And Conservation, Oxford: OUP

Polanyi, K. (1944) The Great Transformation: The Political And Economic Origins Of Our Time. New York: Farrar and Rinehart

Rasmussen, M.B. and C. Lund (2018) 'Reconfiguring Frontier Spaces: The territorialisation of resource control', World Development, 101(1): 388-99

Reddy R.G. and G. Haragopal (1985) 'The Pyraveekar: The Fixer in Rural India', Asian Survey, 25(11): 1148-62

Ribot, J.C. and N.L. Peluso (2003) 'A Theory of Access', Rural Sociology, 68(2): 153-81 Roy, A. (2005) 'Urban Informality: Toward an Epistemology of Planning', 71(2): 147-158 Roy, A. (2009) 'Why India cannot plan its cities: Informality, insurgence, and the idiom of urbanisation', Planning Theory, 8(1): 76-87

Roy, D. (2014) Rural Politics In India: Political Stratification And Governance In West Bengal. Cambridge: Cambridge University Press

Rudolph, L.I. and S.H. Rudolph (1987) In Pursuit Of Lakshmi. The Political Economy Of The Indian State, Chicago: University of Chicago Press.

Sami N (2014) Power to the People? A Study of Bangalore's Urban Task Forces. In: Shatkin G (ed) Contesting The Indian City. Chichester: Wiley Blackwell, pp. 121-144

Samuelson, P.A and W.D. Nordhaus (2010) Economics, Nineteenth Edition, New Delhi: Tata McGraw Hill

Scott, J. C. (1998). Seeing Like A State: How Certain Schemes To Improve The Human Condition Have Failed. New Haven, CT: Yale University Press 
Scott, J.C. (2009) The Art Of Not Being Governed: An Anarchist History Of Upland

Southeast Asia. New Haven, CT: Yale University Press

Sengupta, U. (2013) 'Inclusive development? A state-led land development model in New Town, Kolkata', Environment and Planning C, 31(2): 357-76

Sharma, A. and A. Gupta (Eds.) (2005) The Anthropology Of The State: A Reader. Oxford:

Blackwell

Shatkin G and S Vidyarthi (2014) Introduction. Contesting the Indian City: Global Visions and the Politics of the Local. In Shatkin G (ed) Contesting The Indian City. Chichester: Wiley Blackwell, pp. 1-38

Sikor, T. and C. Lund (2009) (Ed.) The Politics Of Possession: Property, Authority, And Access To Natural Resources. Chichester: Wiley Blackwell

Sinha, A. (2019) 'India's New Porous State: Blurred Boundaries and the Evolving BusinessState Relationship', in C. Jaffrelot, A. Kohli and K. Murali (2019) Business And Politics In India, Delhi: Oxford University Press, pp. 50-94

Steur, L.J. (2015) 'Theorizing Thervoy: Subaltern studies and Dalit praxis in India's land wars', in A.G. Nilsen and S. Roy (Eds.) New Subaltern Politics: Reconceptualizing Hegemony And Resistance In Contemporary India. Delhi: Oxford University Press, pp. 177201

Sud, N. (2007) 'From Land to the Tiller to Land Liberalisation: The Political Economy of Gujarat's Shifting Land Policy', Modern Asian Studies, 41(3): 603-38

Sud, N. (2009) The Indian State in a Liberalizing Landscape, Development and Change, 40(4), $645-65$

Sud, N. (2014) 'Governing India's Land', World Development, 60: 43-56

Sud, N. (2017) 'State, scale and networks in the liberalisation of India's land', Environment and Planning C: Politics and Space 35(1): 76-93

Swyngedouw, E. (2015) Liquid Power: Contested Hydro-Modernities In $20^{\text {th }}$ Century Spain. Cambridge: MIT Press

Ulloa, A. (2005) The Ecological Native: Indigenous Peoples' Movements And Ecogovernmentality In Colombia. New York: Routledge

Weszkalnys, G. (2014) 'Anticipating oil: the temporal politics of a disaster yet to come', The Sociological Review, 62(S1): 211-35

Whatmore, S. (2002) Hybrid Geographies: Natures Cultures Spaces. London: Sage Publications 
Zimmer, A. (2012) 'Enumerating the Semi-Visible: The Politics of Regularing Delhi's Unauthorised Colonies', Economic and Political Weekly, 47(30): 89-97

\section{Bio-sketch}

Nikita Sud is Associate Professor of Development Studies at the University of Oxford, and a Fellow of Wolfson College. She was raised in India and currently lives in Oxford, UK. Her book Unfixed Land: The Making of Land and The Making of India is forthcoming. She is also author of Liberalization, Hindu Nationalism and The State: A Biography of Gujarat (OUP, 2012). Contact address: nikita.sud@qeh.ox.ac.uk

\section{Acknowledgements}

This article benefited from presentations at the Indian Institute of Advanced Study, Jawaharlal Nehru University, and the Modern South Asia seminar at the University of Oxford. Many thanks to the editors and three anonymous journal reviewers who critically engaged with the argument. The long-term research for the study that informs the article was made possible by a number of funders, to whom I am grateful. These include the Research Support Fund of the Oxford Department of International Development, the Academic Support Fund of Wolfson College, the Oxford University Vice Chancellor's Returning Carers' Fund, and the Global Challenges Research Fund (Internal England Grant No. 0006043). 